University of St. Thomas, Minnesota

UST Research Online

2009

\title{
Time-varying Correlations and Optimal Allocation in Emerging Market Equities for the US Investors
}

Thadavillil (Nathan) Jithendranathan

University of St. Thomas, Minnesota, T9JITHENDRAN@stthomas.edu

Heung-Joo Cha

Follow this and additional works at: https://ir.stthomas.edu/ocbfincpub

Part of the Finance and Financial Management Commons

This Article is brought to you for free and open access by the Finance at UST Research Online. It has been accepted for inclusion in Finance Faculty Publications by an authorized administrator of UST Research Online. For more information, please contact asle4660@stthomas.edu. 


\title{
Time-Varying Correlations and Optimal Allocation in Emerging Market Equities for the U.S. Investors
}

\author{
Heung-Joo Cha \\ Assistant Professor \\ University of St. Thomas \\ Thadavillil Jithendranathan* \\ Associate Professor \\ University of St. Thomas
}

\begin{abstract}
Low correlations between asset returns increase the portfolio diversification benefits and for U.S. investors emerging market equities are one such class of assets. Several studies indicate that the correlations between asset returns are time-varying and using unconditional estimates of correlation in a portfolio optimization model can result in misallocation of assets. To overcome this problem we use multivariate GARCH models to estimate the time-varying correlations and use the same in portfolio optimization models. Ex-post return calculations show that unrestricted portfolios created with emerging stock indices and S\&P 500 index outperform the S\&P 500 index by itself. Since investors exhibit strong home bias in their portfolio choice, restricted optimization models are tested. Results indicate that if the total investment in emerging markets is restricted, a minimum investment of twenty percent in emerging markets is required to obtain significant diversification. With investments in each of the emerging market restricted to less that three percent, there was no significant diversification benefit.
\end{abstract}

JEL classifications: F37; G15

Keywords: Emerging Markets; Portfolio Diversification; Time-Varying Correlations

\footnotetext{
*Corresponding author. Department of Finance, Opus College of Business, University of St. Thomas, 2115 Summit Ave., MCH316, St. Paul, MN 55105, USA. Tel.: +1-651-962-5123; fax: +1-651-962-5093.

E-mail address: t9jithendran@stthomas.edu
} 


\section{Introduction}

In the mean-variance optimization model (Markowitz, 1952), an efficient set of portfolios is created by maximizing the expected return of the portfolio and minimizing its risk as measured by the standard deviation. Input variables in this model are the expected returns, standard deviations and correlations of expected returns of the assets in the portfolio. In conventional portfolio optimization models, unconditional estimates of standard deviations and correlations of past asset returns are used as inputs. One of the implicit assumptions in this method of efficient portfolio construction is that the variances and correlations are time-invariant during the holding period of the portfolio (Jobson and Korkie, 1981).

Despite its theoretical appeal, practitioners are generally cautious in applying mean variance optimization models to actual portfolios. Part of the reason for this reluctance may be due to potential problems that can arise due to use of unconditional variances and correlations as inputs. One such problem with the use of unconditional estimates in the model is that it gives higher weights for securities with large expected returns, low variances and negative correlations with other securities in the portfolio (Michaud, 1989). Other studies have indicated that the forecasted returns by the optimization model are highly sensitive to changes in the expected returns and correlations (Best and Grauer, 1991; Chopra and Ziemba, 1993). To alleviate these problems, different studies have suggested possible methods to reduce the sensitivity of 
the mean-variance optimization model by reducing the sensitivity of the model to the input parameters such as variances and correlations. ${ }^{1}$

Studies into the nature of variances and correlations of domestic asset returns have indicated that variances and correlations do change over time. ${ }^{2}$ Similar studies into the correlations of international asset returns by Makridakis and Wheelwright (1974) and Bennett and Kelleher (1988) find that those correlations are also unstable over time. Tests for constancy of correlations generally fall into two categories: testing unconditional correlations using multivariate theory and testing conditional correlations using multivariate GARCH models. ${ }^{3}$ Longin and Solnik (1995) reject the hypothesis of a constant conditional correlation structure by studying the shifts in global correlations from 1960 to 1990 by employing both tests.

There is also a large body of empirical evidence suggesting that the correlations of international stock markets tend to increase conditional on large negatives, or "bear market" returns. ${ }^{4}$ Longin and Solnik (2001) use extreme value theory to show that the correlation of large negative returns is much larger than the correlation of positive returns. Goetzmann, Li and Rouwenhorst (2005) examine the correlation structure of the major world equity markets over 150 years. They find that international equity correlations vary considerably through time.

If the variances and correlations are time-varying, then the next question is which is the best method of estimating these? The most popular method is to use a moving

\footnotetext{
${ }^{1}$ See Jorion (1986), Jorion (1991), Fletcher and Hiller (2001).

${ }^{2}$ See King et al. (1994), Kaplanis (1988), Koch and Koch (1991), Forbes and Rigobon, 2002.

${ }^{3}$ See Kaplanis (1988) for the first and Engle (2002), Tse (2000) for the second category.

${ }^{4}$ See Erb et al (1994), Lin et al. (1994), Longin and Solnik (1995, 2001), Karolyi and Stulz (1996), Ramchand and Susmel (1998), De Santis et al. (2003), Forbes and Rigobon (2002), Boyer et al. (1999), Ang and Bekaert (2002), Bae et al. (2003), and Das and Uppal (2004), Butler and Joaquin (2002).
} 
average specification in which the correlations are estimated using a moving window of time. The drawback of this method is that it gives equal weight to all the observations during that time period used in the moving average calculations. The other method of estimating the time varying correlations is to use multivariate GARCH models. The first set of models of this genre is based on the Constant Correlation Coefficient model of Bollerslev (1990). But the assumption that the correlation coefficient is constant remains the main weakness of these models. The second set of GARCH models is based on the multivariate GARCH models introduced by Kroner and Ng (1998). Even though these multivariate GARCH models are appealing from a theoretical standpoint, computationally they suffer from the problem of estimating too many coefficients at the same time. Engle (2002) introduces a new class of multivariate GARCH models called “Dynamic Conditional Correlation Models (DCC)," which combines flexibility of the univariate models with the theoretical appeal of time-varying correlations. Despite the increased access to international capital markets, investors in many countries continue to hold equity portfolios largely dominated by domestic assets. Thomas et al. (2004) report that U.S. investors held only $14 \%$ of their equity portfolios in foreign stocks at a time where such stocks accounted for $54 \%$ of the world market capitalization at the end of 2003. French and Poterba (1991), Tesar and Werner (1992), and other authors report that portfolio compositions indicate strong home bias. ${ }^{5}$ A survey of fund managers by Lütje and Menkoff (2007) finds that the home bias is mainly related to strong risk aversion and wishful thinking among the fund managers.

An extensive list of academic research documents the benefits of international diversification. Early studies such as Grubel (1968) and Levy and Sarnat (1970) find that

\footnotetext{
${ }^{5}$ See Pastor (2000), Ahearne and et al. (2004).
} 
U.S. investors could have achieved better risk and return opportunities by investing part of their portfolios in foreign equity markets. A portfolio containing international stocks had only half the risk of a portfolio with only U.S. stocks (Solnik, 1995). De Santis and Gerard (1997), and Ang and Bekaert (2002) are some of the other studies that show the significant benefits of international diversification.

Emerging market equities are another class of international assets that have attracted considerable attention in the past few years. Even though equity markets existed in emerging economies, until recently investing in them was difficult due to various restrictions. By the early 1990s many of the emerging countries opened up their equity markets to foreign investors. This process was further accelerated when many of these countries allowed their firms to cross-list their equities in the U.S. markets, mostly in the form of American Depositary Receipts (ADRs). This improvement in investing opportunities in turn has increased the interest in studying the diversification benefits from emerging equity markets. DeSantis (1994), Divecha et al. (1992), Harvey (1995), and other authors document substantial diversification benefits from investing in emerging equity markets. ${ }^{6}$

Another factor that attracted investors to emerging markets is the increase in correlation and the consequent reduction in diversification benefits between equity markets of developed countries. Goetzmann, Li and Rouwenhorst (2005) find that in the last two decades, the investment opportunity set expanded dramatically at the same time correlations of the major markets has increased. As a result, the benefits to international diversification have recently been driven by the existence of emerging capital markets.

\footnotetext{
${ }^{6}$ See Bekaert and Urias (1996).
} 
The primary motive diversification in to emerging markets has been to take advantage of the low correlation between stocks in different national markets.

The major focus of this paper is to develop an empirical portfolio optimization model which allows the variances and correlations of asset returns to vary over time. Using an optimization model that places no restriction on the total amount that can be invested in emerging markets as whole and in each individual country index we estimate the diversification benefit to a U.S. investor. Since many investors exhibit a reluctance to invest more than a certain amount of their investments in emerging markets a restricted model with the maximum amount invested in emerging markets is tested. By gradually increasing the amount invested in emerging markets from one percent upwards the level at which the returns of the diversified portfolios are significantly higher than investing only in the domestic stocks. Similarly another set of efficient portfolios are created with restrictions on the maximum amount invested in each of the emerging markets. Again we gradually increase the investment restricted from one percent in each of the emerging markets and then test the level at which there is significantly higher return from these portfolios as compared to the domestic stocks only portfolio.

The rest of the paper is organized as follows: Section 2 describes the empirical methodology, sources and details of data. Empirical results are discussed in section 3, and section 4 concludes the paper.

\section{Empirical Methodology and Data}

Return of a portfolio with $N$ assets can be written as:

$$
\overline{r_{P}}=\sum_{i=1}^{N} X_{i} \bar{r}_{i}
$$


where $X_{i}$ is the weight of the $i^{t h}$ security in the portfolio and $\bar{r}_{i}$ is the expected return of that asset.

The standard deviation of this portfolio can be expressed as:

$$
\sigma_{P}^{2}=\sum_{i=1}^{N} \sum_{k=1}^{N} X_{i} X_{j} \sigma_{i, k}
$$

where $\sigma_{i, j}$ is the covariance between the two assets $i$ and $j$. The standard method of optimization is to find a set of efficient set of portfolios, which will give the maximum return for a given level of risk.

Mathematically, the optimization problem can be stated as follows:

$$
\operatorname{Min} \sigma_{P}^{2}=\sum_{i=1}^{N} \sum_{k=1}^{N} X_{i} X_{j} \sigma_{i, k}
$$

Subject to the following constraint:

$$
\sum_{i=1}^{N} X_{i}=1
$$

Portfolios can be created with or without short selling constraints. Considering the practical difficulty in short selling emerging market stocks, in this paper the portfolios are constructed with short selling constraints, which require the following additional constraint:

$$
0 \leq X_{i}<1
$$

In the first set of portfolios, called the unrestricted portfolios, there is no limit on how much can be invested in each of the emerging markets as well as the maximum that can be invested in all the nineteen markets together. The only restriction in this model is the short selling constrained given in equation (5) 
As mentioned earlier in this paper, portfolio managers in general are biased towards assets of their home country. This home bias can result in various types of restrictions on the proportion of investment allocated to foreign assets. In this paper the effect of such restrictions on diversification benefits are tested using the following investment constraints.

In the first model with the maximum combined investment in all emerging markets together is restricted with the following additional constraint:

$$
\sum_{j=1}^{19} X_{j} \leq 0.2
$$

where $X_{j}$ is the investment in the $j^{\text {th }}$ emerging market.

In the second restricted model the maximum investment in each of the emerging market is restricted using the following constraint:

$$
X_{j} \leq 0.03 \text { for } j=1 \text { to } 19
$$

Emerging market equity returns exhibit higher volatility than of developed markets and it is also observed that the correlations among the emerging markets and developed markets also exhibit considerable variations over time. To capture the time varying nature of variances and covariances, we use the Dynamic Conditional Correlation (DCC) model of Engle (2002). DCC has a two step procedure for estimating the conditional variances and correlations. It is assumed that the returns of the 20 assets used in constructing the portfolios in this paper are normally distributed with zero mean conditional on the information available at $t-1$.

$$
E_{t-1}\left(r_{t}\right) \sim N\left(0, H_{t}\right)
$$


where $r_{t}$ is the 20x 1 vector of asset returns at time $t$ and $H_{t}$ is the conditional covariance matrix expressed as:

$$
H_{t} \equiv D_{t} R_{t} D_{t}
$$

where $H_{t}$ is the $20 \times 20$ conditional covariance matrix, $R_{t}$ is the conditional correlation matrix and $D_{t}$ is a diagonal matrix with the time-varying standard deviations in the diagonal. In the first step the following univariate GARCH model is used to estimate the diagonal elements $\sigma_{i t}$ of $D_{t}$ using the following $\operatorname{GARCH}(1,1)$ specification.

$$
\sigma_{i t}^{2}=\gamma_{i}+\alpha_{i} r_{i t-1}^{2}+\beta_{i} \sigma_{i t-1}^{2}
$$

The conditional return of each of the assets is standardized by dividing it by its standard deviation obtained in the previous step. This gives the following standardized vector of returns:

$$
E_{t-1}\left(\varepsilon_{t}\right) \sim N\left(0, R_{t}\right)
$$

Correlation between any two assets $i$ and $j$ can be written as:

$$
\rho_{i j, t}=\frac{E_{t-1}\left(\varepsilon_{i, t} \varepsilon_{j, t}\right)}{\sqrt{E_{t-1}\left(\varepsilon_{i, t}^{2}\right) E_{t-1}\left(\varepsilon_{j, t}^{2}\right)}}=E_{t-1}\left(\varepsilon_{i, t} \varepsilon_{j, t}\right)
$$

Using a $\operatorname{GARCH}(1,1)$ specification, the covariance between the random variables can be written as:

$$
q_{i j, t}=\bar{\rho}_{i j}+\alpha\left(\varepsilon_{i, t-1} \varepsilon_{j, t-1}-\bar{\rho}_{i j}\right)+\beta\left(q_{i j, t-1}-\bar{\rho}_{i j}\right)
$$

The unconditional expectation of the cross product is $\bar{\rho}_{i j}$, while for the variances it is $\bar{\rho}_{i j}=1$

The correlation estimator is: 


$$
\rho_{i j, t}=\frac{q_{i j, t}}{\sqrt{q_{i i, t} q_{j j, t}}}
$$

This model will be mean reverting if $\alpha+\beta<1$. The matrix version of this model can then be written as:

$$
Q_{t}=S(1-\alpha-\beta)+\alpha\left(\varepsilon_{t-1} \varepsilon_{t-1}^{\prime}\right)+\beta Q_{t-1}
$$

where $S$ is the unconditional correlation matrix of the disturbance terms and $Q_{t}=\left|q_{i, j, t}\right|$. The log likelihood for this estimator can be written as:

$$
L=-\frac{1}{2} \sum_{t=1}^{T}\left(n \log (2 \pi)+2 \log \left|D_{t}\right|+\log \left|R_{t}\right|+\varepsilon_{t}^{\prime} R_{t}^{-1} \varepsilon_{t}\right)
$$

In the second stage of the estimation the above likelihood estimator is used in estimating the parameters of equation $(10)^{7}$.

The time period covered in this study is January 1996 to December 2004. For emerging markets, we use the Morgan Stanley Capital Market (MSCI) indices and the S\&P 500 index is used as the proxy for the U.S. investor's portfolio. One of the reasons for using the MSCI indices as proxies for the emerging market equities is that several of these indices are currently traded as Exchange Traded Funds (ETF) which allows even small investors to diversify into these equities. The weekly prices for the nineteen emerging market indices and the S\&P 500 index are obtained from Bloomberg and the returns are calculated in U.S. dollar terms. In order to be eligible for inclusion in this study, each index must have continuous data available for the period from January 1996 through December 2004.

\footnotetext{
${ }^{7}$ The statistical program RATS is used in actual estimations.
} 
For the DCC estimators we use sets of five year rolling windows, but to capture the time-varying nature of variances and covariances, the end of the period values of the same was input into the portfolio optimization model. For example, using the DCC model one can estimate 260 variances and correlations for a period of five years. But for estimating the efficient set of portfolios, only the variances and correlations for the last week of the sample period is used. ${ }^{8}$ Following the standard industry practice of using past five years returns and its variances and correlations in portfolio optimization models, weekly averages for the five year period are used as the proxy for expected returns in the portfolio optimization model. ${ }^{9}$

Using the above procedure, we are able to get the weights of the individual stocks in each of the efficient portfolios. Using these weights and the actual returns of each of the twenty indices for periods of one-month, three-months and six-months from the date when the efficient portfolio was created, ex-post returns of the efficient set of portfolios were calculated for each of the sixty months for which efficient sets were calculated. The ex-post performance of efficient set of portfolios with investment in emerging markets are then compared to that of the $\mathrm{S} \& \mathrm{P} 500$ index using the following regression equation:

$$
R_{j, t}=\alpha+\beta \text { Dummy }_{j, t}+\varepsilon_{j, t}
$$

\footnotetext{
${ }^{8}$ For example, for the time period from $1 / 3 / 00$ to $12 / 27 / 04$, the variances and correlations used were taken for the last week of the time period, which is $12 / 27 / 04$. This way it is possible to capture the full extent of the time-varying nature of these variables as it existed at the time of construction of the portfolio.

${ }^{9}$ The length of the time period is less significant in GARCH models since more weight is given to the most recent volatilities rather than the earlier ones. A sensitivity analysis of variations in estimated variance and correlations using three year, four year and five year windows does not show significant differences in point estimates of variances and correlations.
} 
where $R_{j, t}$ is the pooled returns of all eleven efficient portfolios for a period of sixty months and Dummy $y_{j, t}$ is a dummy variable, which is 1 if the portfolio with emerging market indices included in it and 0 if it is estimated using the rolling method. If the regression coefficient $\beta$ is significant, then it indicates that there is a difference in the expost performance of the portfolios. The value of this variable is also the difference between the ex-post returns of portfolios.

\section{Results}

The descriptive statistics of weekly returns of the twenty indices in this study are given in Table 1. Out of the nineteen emerging market indices, seven are from Latin America, seven from Asia, three from Europe and two from Middle East and Africa. Except for the five indices from Asia, all other indices have a positive average return. The negative returns for the Asian indices can be attributed to the financial crisis faced by these countries in the 1990s. All of the emerging market indices have higher standard deviation than the S\&P 500 index, indicating the higher level of risk in investing in these countries. Fifteen out of the twenty indices have negative skewness, which is an indication that these markets have more negative shocks than positive shocks during the time period covered in this study. Excess Kurtosis and Jarque-Bera statistics indicate that none of these markets have returns that are normally distributed.

Summary statistics of average correlations of each of the emerging market indices with the S\&P 500 index for the ten year period is given in Table 2. The results indicate interesting regional contrast in correlations. Israel index has the highest correlation with the U.S. index while Sri Lanka index has the lowest average correlation with the S\&P500 
index. Larger economies of Latin America have higher correlation with the U.S. while the smaller economies have lower correlations. Overall, Asian indices have lower correlation with the U.S. index. A complete correlation matrix is given in Table 2A and as expected, there is high correlation between regional markets, while the same is low with others. Average correlations of each of the four regions with that of S\&P 500 index is plotted in Figure 1. Asian market correlations with S\&P 500 index is consistently the lowest, followed by those of the Eastern European markets. Latin American correlations are comparatively higher with the U.S. index, with greater fluctuations during the five year period from 2000 to 2004. Combined average of correlations of Israel and South Africa with the S\&P 500 index is the highest among all the four regions. This may be due to the higher level of cross listing of stocks from these countries in the U.S. equity markets.

Summary statistics of ex-post returns of efficient portfolios that are created with emerging market indices and S\&P 500 index, as well as S\&P 500 index, are presented in Table 3. For each of the sixty months, one minimum variance portfolio and ten efficient portfolios are created and the ex-post returns of each of these portfolios are calculated for periods of one-month, three-months and six-months. Furthermore, these portfolios are divided into two groups based on the standard deviations of the efficient portfolios. For each month, the sample is divided into a set of low risk portfolios comprising minimum variance portfolio and five of the lowest variance portfolios and another set of high risk portfolios comprising five portfolios with the highest risk.

Average ex-post returns of the efficient set of portfolios with emerging market indices included clearly outperform the returns of S\&P 500 index. As predicted by 
theory, the set of low risk portfolios have lower returns and lower standard deviations, while the high risk portfolios have higher ex-post returns and standard deviations. One of the interesting results is the difference in ex-post returns, with one month having the highest return and six months with the lowest. This may be indirect evidence that the portfolios created with time varying correlations are efficient only for a short duration and the efficient frontier might have changed in the interim due to changes in the underlying correlations.

The results of regressions using equation (17) are given in Table 4. Pooled ex-post returns of efficient portfolios are regressed against the dummy variable that has a value of one for those portfolios that contain emerging market indices. Three sets of regressions are made, one for the total sample, one for the low risk portfolios, and one for the high risk portfolios.

The results indicate that the efficient portfolios created with emerging market indices clearly dominate the returns of S\&P 500 index alone. This shows that the U.S. investors can achieve statistically significant higher returns by diversifying their portfolios to include emerging market stocks. Even though unrestricted optimization may look attractive, many investors are reluctant to diversify more than a certain percentage of their assets into emerging market equities. The summary statistics of weight of individual indices in unrestricted portfolios are given in Table 5. As evidenced in this table, the weights of an individual country index can vary from 0 to 1 , which indicates that it is possible that a certain efficient portfolio will be all invested in one single emerging market equity. From a practical standpoint, this may not be acceptable to many portfolio 
managers. To overcome this problem, we test the portfolio diversification benefits with restrictions on the maximum amount that can be invested in emerging markets.

We first create a set of efficient portfolios that have investment in emerging markets restricted to ten percent of the total investment. Ex-post returns of these portfolios are calculated as in the case of unrestricted portfolios and compared with the ex-post returns of S\&P 500 index for periods of one, three and six months. Regression results comparing the two sets of portfolios are given in Table 6. Results indicate that if the diversification is done with only ten percent in emerging markets, there is no statistically significant improvement in those portfolios over the returns of the S\&P 500 index.

Since the investment restriction at ten percent in emerging markets does not produce a significant diversification benefit, we increase the maximum allowable investment in emerging markets to twenty percent of the total portfolio. As in the case of unrestricted portfolios, the ex-post returns of these portfolios are compared with the returns of S\&P 500 index. The results are given in Table 7. Results show that there is some benefit of diversification, especially for the low risk portfolios.

To study the effect of maximum investment restriction in emerging markets, average weights of each of the twenty assets in the portfolio are calculated and reported in Table 8. Average investment in S\&P 500 Index is $80.96 \%$, indicating that the emerging market share in the portfolios is approximately the maximum allowed limit of twenty percent. When the portfolios are subdivided into low-risk and high risk-portfolios, the weight of emerging markets still is close to the maximum limit of twenty percent. What is interesting is that the investment within the emerging market changes with the 
level of risk. Among all the portfolios, Czech index has the highest percentage of 3.06\%, while both Argentina and Brazil are out of the mix. With low risk portfolios, Peru has the highest share of $3.43 \%$, while Israel has the highest percentage of $4.30 \%$ among the high risk portfolios.

When the restriction on investment in emerging markets is two percent for each of the nineteen countries, there is no significant diversification benefit over the S\&P 500 Index. It is found that an investment limit of three percent in each of the merging markets is required to realize significant diversification benefits. The results of OLS regression on pooled returns with investment in emerging markets restricted to the maximum of 3 percent in each of the countries is given in Table 9. These results indicate that the diversified portfolios have higher returns for both three and six month horizons. These results are consistent for both low and high risk portfolios.

The weights of individual assets with maximum investment in each of the emerging markets limited to 3 percent are given in Table 10. Since there are nineteen emerging markets, the maximum possible investment in all of them together is 57 percent, which leaves a potential investment of only 43 percent in S\&P 500 Index. But the results indicate that for all the portfolios, the average weight of S\&P 500 index was 61.74 percent. Interestingly enough there is investment in all the nineteen markets, but there are times when the investment is zero in any one of them. This in turn keeps the investment in S\&P 500 Index higher than the potential low of 43 percent. 


\section{Conclusions}

In this paper we attempt to estimate the diversification benefits that can arise to a U.S. investor by diversifying into emerging markets. Over the past several years, many of the emerging market economies have gone through several upheavals, which had significant impact on its equity markets. The low level of correlation between the emerging equity markets and the U.S. equities offers both opportunities and challenges to the U.S. investors. Relatively high returns and low correlations offer better diversification benefits, while the high variability in the emerging market equity returns requires better econometric models to capture the time-varying nature of the variances and correlations. The use of the DCC model in estimating correlations has shown to improve the portfolio optimization model. Unrestricted diversification into emerging equity markets offer the greatest diversification, but even with restricted diversification, there is some benefit. 


\section{References}

Ahearne, A.G., Griever, W.L., Warnock, F.E., 2004. Information costs and home bias: an analysis of U.S. holdings of foreign equities. Journal of International Economics 62, 313336.

Ang, A., Bekaert, G., 2002. International asset allocation with regime shifts. Review of Financial Studies 15, 1137-1187.

Bae, K.H., Karolyi, G.A., Stulz, R.M., 2003. A new approach to measuring financial contagion. Review of Financial Studies 16, 717-763.

Bekaert, G., Urias M.S., 1996. Diversification, integration and emerging market closed-end funds. Journal of Finance 51, 835-869.

Bennett, P., Kelleher, J., 1988. The international transmission of stock price dusruption in October 1987. Federal Reserve Bank of NY Quarterly Review 12, 17-33.

Best, M.J., Grauer, R.R., 1991. On the sensitivity of mean-variance-efficient portfolios to changes in asset means: Some analytical and computational results. Review of Financial Studies 4, 315-342.

Bollerslev, T., 1990. Modeling the coherence in short run nominal exchange rates: A multivariate generalized ARCH model. Review of Economics and Statistics 72, 498-505.

Boyer, B.H., Gibson, M.S., Loretan, M., 1999. Pitfalls in tests for changes in correlations. International Finance Discussion Paper 597. Board of Governors of the Federal Reserve System, Washington, D.C. 
Butler, K.C., Joaquin, D.C., 2002. Are the gains from international diversification exaggerated? The influence of downside risk in bear markets. Journal of International Money and Finance 21, 981-1011.

Chopra, V.K., Ziemba, W.T., 1993. The effect of errors in means, variances, and covariances on optimal portfolio choice. The Journal of Portfolio Management 19, 6-11.

Das, S., Uppal, R., 2004. Systemic risk and portfolio choice. Journal of Finance 59, 28092834.

De Santis, G., 1994. Asset pricing and portfolio diversification: Evidence from emerging financial markets, in: Mike Howell, Ed., Investing in Emerging Markets. Euromoney Books, London, UK.

De Santis, G., Gerard, B.,1997. International asset pricing and portfolio diversification with time-varying risk. Journal of Finance 52, 1881-1912.

De Santis, G., Gerard, B., Hillion, P., 2003. The relevance of currency risk in the EMU. Journal of Economics and Business 55, 427-462.

Divecha, A.B., Drach, J., Stefek, D.,1992. Emerging markets: A quantitative perspective. The Journal of Portfolio Management 19, 41-50.

Engle, R., 2002. Dynamic conditional correlation - A simple class of multivariate GARCH models. Journal of Business and Economic Statistic 20, 339-350.

Erb, C., Harvey, C., Viskanta, T., 1994. Forecasting international equity correlations. Financial Analysts Journal 50, 32-45.

Fletcher, J., Hiller, J., 2001. An examination of resampled portfolio efficiency. Financial Analysts Journal 57, 66-74. 
Forbes, K.J., Rigobon, R., 2002. No contagion, only interdependence: Measuring stock market comovements. Journal of Finance 57, 2223-2261.

French, K., Poterba, J.M., 1991. International diversification and international equity markets. American Economic Review 81, 222-226.

Goetzmann, W.N., Li, L., Rouwenhorst, K.G., 2005. Long-term global market correlations. Journal of Business 78, 1-38.

Grubel, H.G., 1968. Internationally diversified portfolios. American Economic Review 68, 1299-1314.

Harvey, C., 1995. Predictable risk and returns in emerging markets. Review of Financial Studies 8, 773-816.

Jobson, J.D., Korkie, B.M., 1981. Putting Markowitz theory to work. The Journal of Portfolio Management 7, 70-74.

Jorion, P., 1986. Bayes-Stein estimation for portfolio analysis. Journal of Financial and Quantitative Analysis 21, 279-292.

Jorion, P., 1991. Bayesian and CAPM estimators of the means: Implications for portfolio selection. Journal of Banking and Finance 15, 717-727.

Kaplanis, E. D., 1988. Stability and forecasting of the comovement measures of international stock market returns. Journal of International Money and Finance 7, 63-75.

Karolyi, G.A., Stulz, R., 1996. Why do markets move together? An investigation of U.S.Japan stock return comovements. Journal of Finance 51, 951-986.

King, M., Sentana, E., Wadhwani, S., 1994. Volatility and links between national stock markets. Econometrica 62, 901-934. 
Koch, P.D., Koch, T.W., 1991. Evolution in dynamic linkages across national stock indexes. Journal of International Money and Finance 10, 231-251.

Kroner, K.F., Ng, V.K., 1998. Modeling asymmetric comovements of assets returns. Review of Financial Studies 11, 817-844.

Levy, H., Sarnat, M., 1970. International diversification of investment portfolios. American Economic Review 60, 668-675.

Lin, W.L., Engle, R.F., Ito, T., 1994. Do bulls and bears move across border? International transmission of stock returns and volatility. Review of Financial Studies 7, 507-538.

Longin, F., Solnik, B., 1995. Is the correlation in international equity returns constant: 19601990? Journal of International Money and Finance 14, 3-26.

Longin, F., Solnik, B., 2001. Extreme correlation of international equity markets. Journal of Finance 56, 649-676.

Lütje, T., Menkoff, L., 2007. What drives home bias? Evidence from fund manager's views. International Journal of Finance and Economics, 12, 21-35.

Makridakis, S.G., Wheelwright, S.C., 1974. An analysis of the interrelationships among the major world stock exchanges. Journal of Business Finance \& Accounting 1, 195-216.

Markowitz, H. M., 1952. Portfolio selection. The Journal of Finance 7, 77-91.

Michaud, R.O., 1989. The Markowitz optimization enigma: Is optimized optimal? Financial Analysts Journal 45, 31-42.

Pastor, L., 2000. Portfolio selection and asset pricing models. Journal of Finance 55, 179223.

Ramchand, L., Susmel. R., 1998. Volatility and cross correlation across major stock markets. Journal of Empirical Finance 5, 397-416. 
Solnik, B., 1995. Why not diversify internationally rather than domestically? Financial Analyst Journal 51, 89-94.

Tesar, L.L., Werner, I., 1992. Home bias and the globalization of securities. NBER Working Paper No. 4218, National Bureau of Economic Research, Cambridge, MA.

Thomas, C., Warnock, F., Wongswan, J., 2004. The performance of international portfolios, Discussion paper, Federal Reserve Board.

Tse, Y., 2000. A test for constant correlations in a multivariate GARCH model. Journal of Econometrics 98, 107-127. 
Table 1

Descriptive Statistics of Weekly Returns from 1/9/95 to 12/27/04

\begin{tabular}{|l|c|c|c|c|c|}
\hline Name & Mean & Std. dev. & Skewness & Kurtosis & $\begin{array}{c}\text { Jarque- } \\
\text { Bera }\end{array}$ \\
\hline Argentina & 0.000082 & 0.053536 & -0.179962 & 2.930136 & 189.1934 \\
\hline Brazil & 0.000814 & 0.055872 & -0.940077 & 4.924036 & 603.0815 \\
\hline Chile & 0.000069 & 0.031103 & -0.181981 & 3.081902 & 209.0640 \\
\hline Columbia & 0.000778 & 0.042099 & 0.079696 & 4.044092 & 355.5843 \\
\hline Mexico & 0.001859 & 0.046191 & -0.609070 & 3.858733 & 355.4454 \\
\hline Peru & 0.001264 & 0.036506 & -0.193074 & 3.630988 & 289.4411 \\
\hline Venezuela & 0.000938 & 0.067299 & -2.391792 & 27.872185 & 17361.0518 \\
\hline India & 0.000551 & 0.040058 & -0.220237 & 1.296609 & 40.7077 \\
\hline Indonesia & -0.001360 & 0.072227 & -0.629979 & 6.388630 & 920.4786 \\
\hline Philippines & -0.002809 & 0.045312 & 0.045774 & 4.393661 & 419.2451 \\
\hline South Korea & 0.000207 & 0.057999 & -0.643377 & 5.111673 & 603.1645 \\
\hline Sri Lanka & -0.000910 & 0.044154 & 0.245534 & 3.984655 & 349.9083 \\
\hline Taiwan & -0.000699 & 0.042088 & -0.045971 & 0.889331 & 17.3528 \\
\hline Thailand & -0.002292 & 0.058182 & 0.247813 & 1.550438 & 57.5162 \\
\hline Czech & 0.002061 & 0.036278 & -0.244786 & 0.888183 & 22.3281 \\
Republic & & & & & \\
\hline Poland & 0.001199 & 0.044671 & 0.077273 & 0.801598 & 14.4674 \\
\hline Russia & 0.002962 & 0.082937 & 0.046448 & 2.455761 & 131.1051 \\
\hline Israel & 0.001535 & 0.036669 & -0.275887 & 1.717239 & 70.6251 \\
\hline South Africa & 0.000645 & 0.033926 & -0.903690 & 2.907456 & 254.4200 \\
\hline S\&P 500 & 0.001859 & 0.023640 & -0.128632 & 1.574898 & 55.2799 \\
\hline
\end{tabular}


Table 2

Average Return Correlations between Weekly Returns of Country Indices and S\&P 500 Index: From 1/4/95 to 12/29/04

\begin{tabular}{|l|c|c|c|c|}
\hline Name & Mean & Std. Dev. & Minimum & Maximum \\
\hline Argentina & 0.33019 & 0.06665 & 0.13037 & 0.54527 \\
\hline Brazil & 0.40235 & 0.00534 & 0.34806 & 0.42068 \\
\hline Chile & 0.39101 & 0.04096 & 0.23281 & 0.98417 \\
\hline Columbia & 0.14262 & 0.07010 & -0.98912 & 0.38939 \\
\hline Mexico & 0.48238 & 0.09092 & 0.15095 & 0.72144 \\
\hline Peru & 0.17341 & 0.05943 & -0.01578 & 0.34908 \\
\hline Venezuela & 0.23263 & 0.05917 & 0.14182 & 0.40440 \\
\hline India & 0.12474 & 0.07731 & -0.65434 & 0.45822 \\
\hline Indonesia & 0.10850 & 0.05807 & -0.16130 & 0.85365 \\
\hline Philippines & 0.17988 & 0.03920 & -0.04369 & 0.37835 \\
\hline South Korea & 0.33444 & 0.02425 & 0.21734 & 0.46451 \\
\hline Sri Lanka & 0.01373 & 0.06349 & -0.29585 & 0.51051 \\
\hline Taiwan & 0.31740 & 0.03325 & 0.08089 & 0.51799 \\
\hline Thailand & 0.22906 & 0.02873 & 0.14779 & 0.27958 \\
\hline Czech Republic & 0.20868 & 0.08153 & -0.13659 & 0.60286 \\
\hline Poland & 0.34545 & 0.07209 & 0.00144 & 0.69638 \\
\hline Russia & 0.23757 & 0.01099 & 0.17530 & 0.29473 \\
\hline Israel & 0.53356 & 0.06570 & 0.19643 & 0.73847 \\
\hline South Africa & 0.38016 & 0.01692 & 0.24980 & 0.49604 \\
\hline
\end{tabular}


Table 2 A

Average Correlations between the Emerging Market Equity Returns and S\&P 500 Index From 1/4/95 to 12/29/04

Panel A: Latin America

\begin{tabular}{|l|l|l|l|l|l|l|l|}
\hline Country & Argentina & Brazil & Chile & Columbia & Mexico & Peru & Venezuela \\
\hline Argentina & & & & & & & \\
\hline Brazil & 0.537 & & & & & & \\
\hline Chile & 0.449 & 0.542 & & & & & \\
\hline Columbia & 0.160 & 0.214 & 0.255 & & & \\
\hline Mexico & 0.177 & 0.222 & 0.195 & 0.171 & & & \\
\hline Peru & 0.095 & 0.161 & 0.177 & 0.031 & 0.408 & & \\
\hline Venezuela & 0.159 & 0.169 & 0.201 & 0.178 & 0.200 & 0.133 & \\
\hline India & 0.273 & 0.318 & 0.300 & 0.159 & 0.164 & 0.169 & 0.083 \\
\hline Indonesia & 0.556 & 0.624 & 0.519 & 0.164 & 0.145 & 0.197 & 0.143 \\
\hline Philippines & 0.344 & 0.425 & 0.399 & 0.224 & 0.218 & 0.205 & 0.106 \\
\hline South Korea & 0.203 & 0.208 & 0.208 & 0.150 & 0.275 & 0.172 & 0.114 \\
\hline Sri Lanka & 0.144 & 0.291 & 0.254 & 0.134 & 0.009 & 0.011 & 0.053 \\
\hline Taiwan & 0.302 & 0.323 & 0.300 & 0.149 & 0.232 & 0.159 & 0.114 \\
\hline Thailand & 0.316 & 0.400 & 0.375 & 0.186 & 0.257 & 0.202 & 0.160 \\
\hline Czech Republic & 0.191 & 0.269 & 0.258 & 0.128 & 0.228 & 0.144 & 0.142 \\
\hline Poland & 0.064 & 0.041 & 0.041 & 0.080 & 0.269 & 0.147 & 0.128 \\
\hline Russia & 0.174 & 0.230 & 0.251 & 0.131 & 0.332 & 0.273 & 0.096 \\
\hline Israel & 0.236 & 0.218 & 0.255 & 0.142 & 0.368 & 0.249 & 0.193 \\
\hline South Africa & 0.154 & 0.182 & 0.186 & 0.111 & 0.381 & 0.384 & 0.146 \\
\hline S\&P 500 Index & 0.330 & 0.402 & 0.391 & 0.143 & 0.482 & 0.173 & 0.233 \\
\hline
\end{tabular}


Panel B: Asia

\begin{tabular}{|l|l|l|l|l|l|l|l|}
\hline Country & \multicolumn{1}{|c|}{ India } & Indonesia & Philippines & $\begin{array}{l}\text { South } \\
\text { Korea }\end{array}$ & Sri Lanka & Taiwan & Thailand \\
\hline India & & & & & & & \\
\hline Indonesia & 0.092 & & & & & & \\
\hline Philippines & 0.153 & 0.465 & & & & & \\
\hline South Korea & 0.242 & 0.198 & 0.247 & & & & \\
\hline Sri Lanka & 0.079 & 0.017 & 0.034 & 0.082 & & & \\
\hline Taiwan & 0.250 & 0.217 & 0.256 & 0.360 & 0.102 & & \\
\hline Thailand & 0.229 & 0.439 & 0.475 & 0.367 & 0.080 & 0.391 & \\
\hline Czech Republic & 0.111 & 0.195 & 0.194 & 0.263 & 0.016 & 0.199 & 0.324 \\
\hline Poland & 0.217 & 0.129 & 0.231 & 0.271 & 0.095 & 0.072 & 0.155 \\
\hline Russia & 0.156 & 0.208 & 0.131 & 0.199 & 0.072 & 0.232 & 0.233 \\
\hline Israel & 0.216 & 0.083 & 0.144 & 0.289 & 0.103 & 0.250 & 0.232 \\
\hline South Africa & 0.224 & 0.165 & 0.228 & 0.332 & 0.095 & 0.096 & 0.267 \\
\hline S\&P 500 Index & 0.125 & 0.109 & 0.180 & 0.334 & 0.014 & 0.238 & 0.295 \\
\hline
\end{tabular}

Panel C: Europe, Middle East and Africa

\begin{tabular}{|l|c|c|c|c|c|}
\hline Country & $\begin{array}{c}\text { Czech } \\
\text { Republic }\end{array}$ & Poland & Russia & Israel & South Africa \\
\hline Czech Republic & & & & & \\
\hline Poland & 0.207 & & & & \\
\hline Russia & 0.244 & 0.393 & & & \\
\hline Israel & 0.250 & 0.251 & 0.281 & & \\
\hline South Africa & 0.156 & 0.166 & 0.328 & 0.330 & \\
\hline S\&P 500 Index & 0.342 & 0.291 & 0.412 & 0.534 & 0.380 \\
\hline
\end{tabular}


Table 3

Descriptive Statistics of Ex-post Returns of Unrestricted Portfolios

\begin{tabular}{|c|c|c|c|c|c|}
\hline Name & Mean & Std. dev. & Skewness & $\begin{array}{l}\text { Kurtosis } \\
\text { (excess) }\end{array}$ & $\begin{array}{l}\text { Jarque- } \\
\text { Bera }\end{array}$ \\
\hline \multicolumn{6}{|c|}{ All efficient portfolios } \\
\hline One month & 0.002935 & 0.015077 & -0.170499 & 1.386947 & 56.097263 \\
\hline Three months & 0.001901 & 0.008655 & -0.103844 & 0.136835 & 1.701110 \\
\hline Six months & 0.001793 & 0.006249 & 0.258861 & -0.554346 & 15.821713 \\
\hline \multicolumn{6}{|c|}{ Low risk efficient portfolios } \\
\hline One month & 0.002435 & 0.012458 & -0.380648 & -0.106883 & 8.864917 \\
\hline Three months & 0.001922 & 0.007512 & 0.036058 & -0.810354 & 9.928110 \\
\hline Six months & 0.001914 & 0.006063 & 0.273143 & -0.533190 & 8.740808 \\
\hline \multicolumn{6}{|c|}{ High risk efficient portfolios } \\
\hline One month & 0.003535 & 0.017721 & -0.125021 & 1.238892 & 19.967181 \\
\hline Three months & 0.001875 & 0.009867 & -0.170876 & 0.228001 & 2.109738 \\
\hline Six months & 0.001649 & 0.006473 & 0.253736 & -0.582849 & 7.465511 \\
\hline \multicolumn{6}{|c|}{ S\&P 500 Index } \\
\hline One month & -0.000647 & 0.012193 & -0.543685 & 0.360447 & 36.088157 \\
\hline Three months & -0.000384 & 0.006058 & -0.737514 & 0.631982 & 70.815564 \\
\hline Six months & -0.000401 & 0.004001 & -0.286407 & -0.344531 & 12.287478 \\
\hline
\end{tabular}




\section{Table 4}

OLS Regression Output for Ex-post Returns against Efficient Portfolio Dummy

\begin{tabular}{|c|c|c|c|c|}
\hline & $\begin{array}{c}\alpha \\
\text { (t-stat) } \\
\end{array}$ & $\begin{array}{c}\beta \\
(t-s t a t) \\
\end{array}$ & $\begin{array}{l}\text { Adj. } \mathbf{R}^{2} \\
\text { (F-stat) }\end{array}$ & Obs. \\
\hline \multicolumn{5}{|l|}{ All portfolios } \\
\hline One month & $\begin{array}{l}-0.00064 \\
(1.21238)\end{array}$ & $\begin{array}{c}0.00358 \\
(4.74580)\end{array}$ & $\begin{array}{c}0.016055 \\
(22.5226)\end{array}$ & 1320 \\
\hline Three months & $\begin{array}{c}-0.00038 \\
(1.31890) \\
\end{array}$ & $\begin{array}{c}0.00228 \\
(5.55414)\end{array}$ & $\begin{array}{c}0.022129 \\
(30.8485)^{*}\end{array}$ & 1320 \\
\hline Six months & $\begin{array}{c}-0.00040 \\
(1.96532)^{\text {** }}\end{array}$ & $\begin{array}{c}0.00219 \\
(7.59882)\end{array}$ & $\begin{array}{c}0.041245 \\
(57.7421)^{*}\end{array}$ & 1320 \\
\hline \multicolumn{5}{|c|}{ Low risk portfolios } \\
\hline One month & $\begin{array}{c}-0.00064 \\
(0.99570)\end{array}$ & $\begin{array}{c}0.00308 \\
(3.35359)\end{array}$ & $\begin{array}{c}0.014051 \\
(11.2466)^{*}\end{array}$ & 720 \\
\hline Three months & $\begin{array}{c}-0.00038 \\
(1.06609) \\
\end{array}$ & $\begin{array}{c}0.00230 \\
(4.53164)\end{array}$ & $\begin{array}{c}0.026452 \\
(20.5357)^{*}\end{array}$ & 720 \\
\hline Six months & $\begin{array}{l}-0.00040 \\
(1.48244)\end{array}$ & $\begin{array}{c}0.00231 \\
(6.04661)\end{array}$ & $\begin{array}{c}0.047129 \\
(36.5615)^{*}\end{array}$ & 720 \\
\hline \multicolumn{5}{|c|}{ High risk portfolios } \\
\hline One month & $\begin{array}{l}-0.00064 \\
(0.73662)\end{array}$ & $\begin{array}{c}0.00418 \\
(3.36645)\end{array}$ & $\begin{array}{c}0.016958 \\
(11.3330)^{*}\end{array}$ & 600 \\
\hline Three months & $\begin{array}{l}-0.00038 \\
(0.81116)\end{array}$ & $\begin{array}{c}0.00225 \\
(3.37752)^{*}\end{array}$ & $\begin{array}{c}0.017078 \\
(11.4076)\end{array}$ & 600 \\
\hline Six months & $\begin{array}{l}-0.00040 \\
(1.29170)\end{array}$ & $\begin{array}{c}0.00205 \\
(4.66510)\end{array}$ & $\begin{array}{c}0.033502 \\
(21.7632)^{*}\end{array}$ & 600 \\
\hline
\end{tabular}

* Significant at $1 \%$

** Significant at 5\%

*** Significant at $10 \%$ 
Table 5

Weights of Individual Indices in Unrestricted Portfolios

\begin{tabular}{|c|c|c|c|c|c|c|c|c|c|c|c|c|}
\hline & \multicolumn{3}{|c|}{ All portfolios } & \multicolumn{3}{|c|}{$\begin{array}{c}\text { Minimum variance } \\
\text { portfolio }\end{array}$} & \multicolumn{3}{|c|}{ Low risk portfolios } & \multicolumn{3}{|c|}{ High risk portfolios } \\
\hline & Mean & $\begin{array}{l}\text { Std. } \\
\text { dev. }\end{array}$ & $\begin{array}{l}\text { Min.- } \\
\text { Max. }\end{array}$ & Mean & $\begin{array}{l}\text { Std. } \\
\text { dev. }\end{array}$ & $\begin{array}{l}\text { Min.- } \\
\text { Max. }\end{array}$ & Mean & $\begin{array}{l}\text { Std. } \\
\text { dev. }\end{array}$ & $\begin{array}{l}\text { Min.- } \\
\text { Max. }\end{array}$ & Mean & $\begin{array}{l}\text { Std. } \\
\text { dev. }\end{array}$ & $\begin{array}{l}\text { Min.- } \\
\text { Max. }\end{array}$ \\
\hline Argentina & 0.0017 & 0.0103 & $0-0.20$ & 0.0082 & 0.0257 & $0-0.20$ & 0.0018 & 0.0096 & $0-0.14$ & 0.0017 & 0.0019 & $0-0.20$ \\
\hline Brazil & 0.0001 & 0.0013 & $0-0.03$ & 0.0004 & 0.0033 & $0-0.03$ & 0.0001 & 0.0012 & $0-0.02$ & 0.0001 & 0.0000 & $0-0.00$ \\
\hline Chile & 0.0279 & 0404 & $0-0.19$ & 0.0803 & 0.0387 & $0-0.19$ & 0.0437 & 0.0418 & $0-0.18$ & 0.0279 & 076 & -0.07 \\
\hline Columbia & 0.0463 & 0.1072 & $0-0.83$ & 0.0790 & 0.1197 & $\begin{array}{l}0.01- \\
0.76\end{array}$ & 0.0541 & 071 & $0-0.83$ & 0.0463 & 027 & -0.54 \\
\hline Czech & 0.1248 & 1424 & $0-1.00$ & 0.0749 & 0.0283 & $0-0.14$ & 0.1206 & 0.0770 & $0-0.47$ & 0.1248 & 1946 & -1.00 \\
\hline India & 0.0484 & 0.0449 & $0-0.25$ & 0.0761 & 0.0369 & $\begin{array}{l}0.01- \\
0.22 \\
\end{array}$ & 0.0699 & 0.0412 & $0-0.25$ & 0.0484 & 0.0336 & $0-0.12$ \\
\hline Indonesia & 0068 & 2071 & $0-0.31$ & 0.0111 & 0.0369 & $0-0.28$ & 0.0099 & 0.0332 & $0-0.31$ & 0.0068 & 0.1050 & $0-0.10$ \\
\hline Israel & 0.0390 & 0.0529 & \begin{tabular}{|l|}
$0-0.39$ \\
\end{tabular} & 0.0325 & 0.0240 & $0-0.09$ & 0.0437 & 0.0412 & $0-0.16$ & 0.0390 & 0.0656 & $0-0.39$ \\
\hline Mexico & 0.0380 & 0.1179 & 0-1.00 & 0.0114 & 0.0272 & $0-0.17$ & 0.0278 & 0.0354 & $0-0.18$ & 0.0380 & 0.1696 & $0-1.00$ \\
\hline Peru & 0.0822 & 0.1039 & $0-0.89$ & 0.1171 & 0.0685 & $0-0.36$ & 0.1220 & 0.1165 & $0-0.87$ & 0.0822 & 0.0727 & $0-0.40$ \\
\hline Philippir & 0.0062 & 0.0214 & $0-0.25$ & 0.0409 & 0.0438 & $0-0.25$ & 0.0055 & 0.0187 & $0-0.20$ & 0.0062 & 0.0000 & $0-0.00$ \\
\hline Poland & 0.0045 & 0.0170 & $0-0.16$ & 0.0131 & 0.0263 & $0-0.16$ & 0.0063 & 0.0207 & $0-0.15$ & 0.0045 & 0.0066 & $0-0.06$ \\
\hline Russia & 0.1045 & 0.2435 & $0-1.00$ & 0.0002 & 0.0010 & $0-0.01$ & 0.0210 & 0.0534 & $0-0.35$ & 0.1045 & 0.3281 & $0-1.00$ \\
\hline $\begin{array}{l}\text { South } \\
\text { Africa }\end{array}$ & 0.0140 & 0.0 & $0-0.25$ & 0.0393 & 0.0311 & $0-0.21$ & 0.0225 & 0.0334 & $0-0.25$ & 0.0140 & 0.0037 & $0-0.05$ \\
\hline $\begin{array}{l}\text { South } \\
\text { Korea }\end{array}$ & 0.0703 & 0.1888 & $0-1.00$ & 0.0010 & 0.0051 & $0-0.04$ & 0.0244 & 0.0561 & $0-0.37$ & 0.0703 & 0.2622 & $0-1.00$ \\
\hline Sri Lanka & 0.0450 & 0.0508 & $0-0.22$ & 0.1007 & 0.0336 & $0-0.17$ & 0.0684 & 0.0454 & $0-0.22$ & 0.0450 & 0.0322 & $0-0.22$ \\
\hline Taiwan & 0.0256 & 0.0591 & $0-0.44$ & 0.0492 & 0.0727 & $0-0.40$ & 0.0376 & 0.0718 & $0-0.44$ & 0.0256 & 0.0311 & $0-0.28$ \\
\hline Thailand & 0.0041 & 0.0317 & $0-0.73$ & 0.0152 & 0.0948 & $0-0.73$ & 0.0031 & 0.0117 & $0-0.10$ & 0.0041 & 0.0166 & $0-0.13$ \\
\hline Venezuela & 0.0089 & 0.0160 & 0-0.10 & 0.0174 & 0.0152 & $0-0.06$ & 0.0115 & 0.0176 & $0-0.10$ & 0.0089 & 0.0131 & $0-0.10$ \\
\hline S\&P 500 & 0.3016 & 0.2698 & 0-1.00 & 0.2321 & 0.0940 & $0-0.46$ & 0.2562 & 0.2005 & $0-0.68$ & 0.2774 & 0.3417 & $0-1.00$ \\
\hline
\end{tabular}


Table 6

OLS Regression Output for Ex-post Returns against Efficient Portfolio Dummy with $90 \%$ Investment in S\&P 500 Index

\begin{tabular}{|c|c|c|c|c|}
\hline & $\begin{array}{c}\alpha \\
\text { (t-stat) }\end{array}$ & $\begin{array}{c}\beta \\
\text { (t-stat) }\end{array}$ & $\begin{array}{l}\text { Adj. } \mathbf{R}^{2} \\
\text { (F-stat) }\end{array}$ & Obs. \\
\hline \multicolumn{5}{|l|}{ All portfolios } \\
\hline One month & $\begin{array}{c}-0.00064 \\
(1.48246) \\
\end{array}$ & $\begin{array}{c}0.00050 \\
(0.82067)\end{array}$ & $\begin{array}{c}-0.000248 \\
(0.6735)\end{array}$ & 1320 \\
\hline Three months & $\begin{array}{c}-0.00038 \\
(1.71079)^{* * *}\end{array}$ & $\begin{array}{l}-0.00019 \\
(0.62511)\end{array}$ & $\begin{array}{c}-0.000462 \\
(0.3908)\end{array}$ & 1320 \\
\hline Six months & $\begin{array}{c}-0.00040 \\
(2.72159)^{*}\end{array}$ & $\begin{array}{l}-0.00027 \\
(1.29568)\end{array}$ & $\begin{array}{c}0.000514 \\
(1.6788)\end{array}$ & 1320 \\
\hline \multicolumn{5}{|c|}{ Low risk portfolios } \\
\hline One month & $\begin{array}{c}-0.00064 \\
(1.09567) \\
\end{array}$ & $\begin{array}{c}0.00060 \\
(0.72120) \\
\end{array}$ & $\begin{array}{c}-0.000668 \\
(0.5201)\end{array}$ & 720 \\
\hline Three months & $\begin{array}{c}-0.00038 \\
(1.26486) \\
\end{array}$ & $\begin{array}{c}-0.00014 \\
(0.34423) \\
\end{array}$ & $\begin{array}{c}-0.001228 \\
(0.1185) \\
\end{array}$ & 720 \\
\hline Six months & $\begin{array}{c}-0.00040 \\
(1.99509)^{*}\end{array}$ & $\begin{array}{c}-0.00017 \\
(-0.60930)\end{array}$ & $\begin{array}{c}-0.000875 \\
(0.3712)\end{array}$ & 720 \\
\hline \multicolumn{5}{|c|}{ High risk portfolios } \\
\hline One month & $\begin{array}{c}-0.00064 \\
(0.99699) \\
\end{array}$ & $\begin{array}{c}0.00039 \\
(0.42672) \\
\end{array}$ & $\begin{array}{c}-0.001367 \\
(0.1821) \\
\end{array}$ & 600 \\
\hline Three months & $\begin{array}{c}-0.00038 \\
(1.15007)\end{array}$ & $\begin{array}{l}-0.00025 \\
(0.54891)\end{array}$ & $\begin{array}{c}-0.001168 \\
(0.3013)\end{array}$ & 600 \\
\hline Six months & $\begin{array}{c}-0.00040 \\
(1.84934)^{* * *}\end{array}$ & $\begin{array}{c}-0.00038 \\
(1.25919) \\
\end{array}$ & $\begin{array}{c}0.000977 \\
(1.5856) \\
\end{array}$ & 600 \\
\hline
\end{tabular}

* Significant at $1 \%$

** Significant at $5 \%$

*** Significant at $10 \%$ 


\section{Table 7}

OLS Regression Output for Ex-post Returns against Efficient Portfolio Dummy with $80 \%$ Investment in S\&P 500 Index

\begin{tabular}{|c|c|c|c|c|}
\hline & $\begin{array}{c}\alpha \\
\text { (t-stat) }\end{array}$ & $\begin{array}{c}\beta \\
\text { (t-stat) }\end{array}$ & $\begin{array}{l}\text { Adj. } R^{2} \\
\text { (F-stat) }\end{array}$ & Obs. \\
\hline \multicolumn{5}{|l|}{ All portfolios } \\
\hline One month & $\begin{array}{c}-0.00064 \\
(1.38786) \\
\end{array}$ & $\begin{array}{c}0.00111 \\
(1.68837)^{* * * *}\end{array}$ & $\begin{array}{l}0.001401 \\
(2.8506)^{* * * *}\end{array}$ & 1320 \\
\hline Three months & $\begin{array}{l}-0.00038 \\
(1.61800)\end{array}$ & $\begin{array}{c}0.00058 \\
(1.74684)^{* * * *}\end{array}$ & $\begin{array}{c}0.001553 \\
(3.0514)^{* * * *}\end{array}$ & 1320 \\
\hline Six months & $\begin{array}{c}-0.00040 \\
(2.50284)^{* *}\end{array}$ & $\begin{array}{c}0.00049 \\
(2.19514)^{* *}\end{array}$ & $\begin{array}{c}0.002887 \\
(4.8186)^{* *}\end{array}$ & 1320 \\
\hline \multicolumn{5}{|c|}{ Low risk portfolios } \\
\hline One month & $\begin{array}{l}-0.00064 \\
(1.04203)\end{array}$ & $\begin{array}{c}0.00089 \\
(1.01755)\end{array}$ & $\begin{array}{c}0.000049 \\
(1.0354)\end{array}$ & 720 \\
\hline Three months & $\begin{array}{l}-0.00038 \\
(1.20574)\end{array}$ & $\begin{array}{c}0.00058 \\
(1.30376)\end{array}$ & $\begin{array}{c}0.000972 \\
(1.6998)\end{array}$ & 720 \\
\hline Six months & $\begin{array}{c}0.00040 \\
(1.84872)^{* * *}\end{array}$ & $\begin{array}{c}0.00054 \\
(1.76473)^{* * * *}\end{array}$ & $\begin{array}{c}0.002932 \\
(3.1143)^{* * * *}\end{array}$ & 720 \\
\hline \multicolumn{5}{|c|}{ High risk portfolios } \\
\hline One month & $\begin{array}{l}-0.00064 \\
(0.91672)\end{array}$ & $\begin{array}{c}0.00137 \\
(1.37926)\end{array}$ & $\begin{array}{l}0.001504 \\
(1.9024)\end{array}$ & 600 \\
\hline Three months & $\begin{array}{c}-0.00038 \\
(1.07763)\end{array}$ & $\begin{array}{c}0.00058 \\
(1.16128)\end{array}$ & $\begin{array}{l}0.000582 \\
(1.3486)\end{array}$ & 600 \\
\hline Six months & $\begin{array}{c}-0.00040 \\
(1.68445)^{* * * *}\end{array}$ & $\begin{array}{c}0.00044 \\
(1.32069)\end{array}$ & $\begin{array}{l}0.001241 \\
(1.7442)\end{array}$ & 600 \\
\hline
\end{tabular}

Significant at $1 \%$

** Significant at 5\%

${ }^{* * *}$ Significant at $10 \%$ 
Table 8

Weights of Individual Indices in Portfolios with Maximum 20 Percent Investment in Emerging Markets

\begin{tabular}{|c|c|c|c|c|c|c|c|c|c|c|c|c|}
\hline & \multicolumn{3}{|c|}{ All portfolios } & \multicolumn{3}{|c|}{$\begin{array}{c}\text { Minimum variance } \\
\text { portfolio }\end{array}$} & \multicolumn{3}{|c|}{ Low risk portfolios } & \multicolumn{3}{|c|}{ High risk portfolios } \\
\hline & Mean & $\begin{array}{l}\text { Std. } \\
\text { dev. }\end{array}$ & $\begin{array}{l}\text { Min.- } \\
\text { Max. }\end{array}$ & Mean & $\begin{array}{l}\text { Std. } \\
\text { dev. }\end{array}$ & $\begin{array}{l}\text { Min.- } \\
\text { Max. }\end{array}$ & Mean & $\begin{array}{l}\text { Std. } \\
\text { dev. }\end{array}$ & $\begin{array}{l}\text { Min.- } \\
\text { Max. }\end{array}$ & Mean & $\begin{array}{l}\text { Std. } \\
\text { dev. }\end{array}$ & $\begin{array}{l}\text { Min.- } \\
\text { Max. }\end{array}$ \\
\hline Argentina & 0.0000 & 0.0005 & $0-0.01$ & 0.0003 & 0.0016 & $0-0.01$ & 0.0000 & 0.0000 & $0-0.00$ & 0.0000 & 0.0000 & $0-0.00$ \\
\hline Brazil & 0.0000 & 0.0000 & $0-0.00$ & 0.0000 & 0.0000 & $0-0.00$ & 0.0000 & 0.0000 & $0-0.00$ & 0.0000 & 0.0000 & $0-0.00$ \\
\hline Chile & 0.0004 & 0.0026 & $0-0.03$ & 0.0006 & 0.0026 & $0-0.02$ & 0.0006 & 0.0034 & $0-0.03$ & 0.0000 & 0.0007 & $0-0.01$ \\
\hline Columbia & 0.0099 & 0.0254 & $0-0.20$ & 0.0244 & 0.0359 & $0-0.20$ & 0.0138 & 0.0293 & $0-0.14$ & 0.0009 & 0.0060 & $0-0.07$ \\
\hline Czech & 0.0306 & 0.0355 & $0-0.19$ & 0.0178 & 0.0198 & $0-0.07$ & 0.0356 & 0.0301 & $0-0.14$ & 0.0278 & 0.0434 & $0-0.19$ \\
\hline India & 0.0298 & 0.0283 & $0-0.11$ & 0.0306 & 0.0240 & $0-0.08$ & 0.0356 & 0.0299 & $0-0.11$ & 0.0222 & 0.0254 & $0-0.10$ \\
\hline Indonesia & 0.0030 & 0.0107 & \begin{tabular}{|l|}
$0-0.09$ \\
\end{tabular} & 0.0058 & 0.0149 & $0-0.09$ & 0.0040 & 0.0126 & $0-0.07$ & 0.0010 & 0.0049 & $0-0.03$ \\
\hline Israel & 0.0231 & 0.0412 & $0-0.18$ & 0.0011 & 0.0063 & $0-0.05$ & 0.0124 & 0.0233 & $0-0.12$ & 0.0430 & 0.0544 & $0-0.18$ \\
\hline Mexico & 0.0090 & \begin{tabular}{|l}
0.0252 \\
\end{tabular} & 0-0.18 & 0.0000 & 0.0000 & $0-0.00$ & 0.0021 & 076 & 0-0.05 & 0.0202 & .0367 & -0.18 \\
\hline Peru & 0.0278 & 0.0332 & 0-0.15 & 0.0486 & 0.0350 & $0-0.15$ & 0.0379 & 0.0343 & $0-0.12$ & 0.0091 & 0.0193 & $0-0.10$ \\
\hline Philippines & 0.0011 & 0.0049 & $0-0.05$ & 0.0078 & 0.0120 & $0-0.05$ & 0.0004 & 0.0023 & $0-0.03$ & 0.0000 & 0.0000 & $0-0.00$ \\
\hline Poland & 0.0010 & 0.0065 & 0-0.06 & 0.0005 & 0.0039 & $0-0.03$ & 0.0012 & 0.0064 & 0-0.05 & 0.0010 & 0.0072 & $0-0.06$ \\
\hline Russia & 0.0142 & 0.0324 & $0-0.19$ & 0.0003 & 0.0018 & $0-0.01$ & 0.0091 & 0.0235 & $0-0.16$ & 0.0246 & 0.0423 & $0-0.19$ \\
\hline $\begin{array}{l}\text { South } \\
\text { Africa }\end{array}$ & 0.0000 & \begin{tabular}{|l|l|}
0.0003 \\
\end{tabular} & $0-0.01$ & 0.0001 & 0.0008 & $0-0.01$ & 0.0000 & 0.0003 & $0-0.00$ & 0.0000 & 0.0000 & $0-0.00$ \\
\hline $\begin{array}{l}\text { South } \\
\text { Korea }\end{array}$ & 0.0092 & 0.0280 & $0-0.19$ & 0.0000 & 0.0000 & $0-0.00$ & 0.0081 & 0.0249 & $0-0.18$ & 0.0131 & 0.0342 & $0-0.19$ \\
\hline Sri Lanka & 0.0190 & 0.0245 & 0-0.09 & 0.0463 & 0.0181 & $0-0.08$ & 0.0234 & 0.0243 & $0-0.09$ & 0.0056 & 0.0165 & $0-0.07$ \\
\hline Taiwan & 0.0080 & \begin{tabular}{|l|}
0.0244 \\
\end{tabular} & 0-0.18 & 0.0095 & 0.0279 & $0-0.15$ & 0.0112 & 0.0293 & 0-0.18 & 0.0036 & 0.0134 & 0-0.09 \\
\hline Thailand & 0.0012 & 0.0115 & $0-0.20$ & 0.0040 & 0.0259 & $0-0.20$ & 0.0009 & 0.0093 & $0-0.12$ & 0.0007 & 0.0064 & $0-0.07$ \\
\hline Venezuela & 0.0031 & 0.0079 & $0-0.04$ & 0.0023 & 0.0081 & $0-0.04$ & 0.0032 & 0.0075 & $0-0.04$ & 0.0034 & 0.0083 & $0-0.04$ \\
\hline S\&P 500 & 0.8096 & 0.0349 & $0.8-1$ & 0.8000 & 0.0000 & $0.8-0.8$ & 0.8005 & 0.0041 & $\begin{array}{l}0.8- \\
0.85\end{array}$ & 0.8238 & 0.0525 & $0-0.8-1$ \\
\hline
\end{tabular}


Table 9

OLS Regression Output for Ex-post Returns against Efficient Portfolio Dummy with Restricting the Maximum Investment in Each of the Emerging Markets to 3

Percent

\begin{tabular}{|c|c|c|c|c|}
\hline & $\begin{array}{c}\alpha \\
(t-s t a t)\end{array}$ & $\begin{array}{c}\beta \\
(t-s t a t)\end{array}$ & $\begin{array}{l}\text { Adj. } \mathbf{R}^{2} \\
\text { (F-stat) }\end{array}$ & Obs. \\
\hline \multicolumn{5}{|l|}{ All portfolios } \\
\hline One month & $\begin{array}{l}-0.00036 \\
(0.76785)\end{array}$ & $\begin{array}{c}0.00104 \\
(1.54649)\end{array}$ & $\begin{array}{l}0.00124 \\
(2.3916)\end{array}$ & 1320 \\
\hline Three months & $\begin{array}{c}-0.00062 \\
(2.37243)^{* *}\end{array}$ & $\begin{array}{c}0.00107 \\
(2.86999)^{*}\end{array}$ & $\begin{array}{c}0.00644 \\
(8.2369)^{*}\end{array}$ & 1320 \\
\hline Six months & $\begin{array}{c}-0.00083 \\
(4.58027)^{*}\end{array}$ & $\begin{array}{c}0.00104 \\
(4.03537)^{*}\end{array}$ & $\begin{array}{c}0.01350 \\
(16.2842)^{*}\end{array}$ & 1320 \\
\hline \multicolumn{5}{|c|}{ Low risk portfolios } \\
\hline One month & $\begin{array}{c}-0.00024 \\
(0.38157)\end{array}$ & $\begin{array}{c}0.00104 \\
(1.14583) \\
\end{array}$ & $\begin{array}{l}0.00053 \\
(1.3129)\end{array}$ & 720 \\
\hline Three months & $\begin{array}{c}-0.00056 \\
(1.58510) \\
\end{array}$ & $\begin{array}{c}0.00111 \\
(2.19217)^{* *}\end{array}$ & $\begin{array}{c}0.00635 \\
(4.8056)^{*}\end{array}$ & 720 \\
\hline Six months & $\begin{array}{c}-0.00087 \\
(3.49863)^{*}\end{array}$ & $\begin{array}{c}0.00113 \\
(3.18473)^{*}\end{array}$ & $\begin{array}{c}0.01513 \\
(10.1425)^{*}\end{array}$ & 720 \\
\hline \multicolumn{5}{|c|}{ High risk portfolios } \\
\hline One month & $\begin{array}{l}-0.00050 \\
(0.70783)\end{array}$ & $\begin{array}{c}0.00104 \\
(1.03817)\end{array}$ & $\begin{array}{l}0.00014 \\
(1.0778)\end{array}$ & 600 \\
\hline Three months & $\begin{array}{c}-0.00068 \\
(1.77403)^{* * *}\end{array}$ & $\begin{array}{c}0.00101 \\
(1.85546)^{* * *}\end{array}$ & $\begin{array}{c}0.00467 \\
(3.4427)^{\text {**** }}\end{array}$ & 600 \\
\hline Six months & $\begin{array}{l}-0.00078 \\
(2.95845)^{*}\end{array}$ & $\begin{array}{c}0.00094 \\
(2.49672)^{* *}\end{array}$ & $\begin{array}{c}0.00994 \\
(6.2336)^{* *}\end{array}$ & 600 \\
\hline
\end{tabular}

* Significant at $1 \%$

** Significant at $5 \%$

*** Significant 
Table 10

Weights of Individual Indices in Portfolios with Maximum 3 Percent Investment in each of the Emerging Markets

\begin{tabular}{|c|c|c|c|c|c|c|c|c|c|c|c|c|}
\hline & \multicolumn{3}{|c|}{ All portfolios } & \multicolumn{3}{|c|}{$\begin{array}{c}\text { Minimum variance } \\
\text { portfolio }\end{array}$} & \multicolumn{3}{|c|}{ Low risk portfolios } & \multicolumn{3}{|c|}{ High risk portfolios } \\
\hline & Mean & $\begin{array}{l}\text { Std. } \\
\text { dev. }\end{array}$ & $\begin{array}{l}\text { Min.- } \\
\text { Max. }\end{array}$ & Mean & $\begin{array}{l}\text { Std. } \\
\text { dev. }\end{array}$ & $\begin{array}{l}\text { Min.- } \\
\text { Max. }\end{array}$ & Mean & $\begin{array}{l}\text { Std. } \\
\text { dev. }\end{array}$ & $\begin{array}{l}\text { Min.- } \\
\text { Max. }\end{array}$ & Mean & $\begin{array}{l}\text { Std. } \\
\text { dev. }\end{array}$ & $\begin{array}{l}\text { Min.- } \\
\text { Max. }\end{array}$ \\
\hline Argentina & 0.0170 & 0.0136 & $0-0.03$ & 0.0254 & 0.0100 & $0-0.03$ & 0.0199 & 0.0125 & $0-0.03$ & 0.0124 & 0.0136 & $0-0.03$ \\
\hline Brazil & 0.0114 & 0.0141 & $0-0.03$ & 0.0145 & 0.0140 & $0-0.03$ & 0.0119 & 0.0142 & $0-0.03$ & 0.0101 & 0.0140 & $0-0.03$ \\
\hline Chile & 0.0232 & 0.0122 & $0-0.03$ & 0.0295 & 0.0039 & $0-0.03$ & 0.0289 & 0.0052 & $0-0.03$ & 0.0164 & 0.0144 & $0-0.03$ \\
\hline Columbia & 0.0198 & 0.0136 & $0-0.03$ & 0.0295 & 0.0039 & $0-0.03$ & 0.0258 & 0.0091 & $0-0.03$ & 0.0120 & 0.0143 & $0-0.03$ \\
\hline Czech & 0.0269 & 0.0088 & $0-0.03$ & 0.0294 & 0.0040 & $0-0.03$ & 0.0288 & 0.0058 & $0-0.03$ & 0.0246 & 0.0111 & $0-0.03$ \\
\hline India & 0.0282 & 0.0069 & $0-0.03$ & 0.0295 & 0.0039 & $0-0.03$ & 0.0294 & 0.0043 & $0-0.03$ & 0.0268 & 0.0089 & $0-0.03$ \\
\hline Indonesia & 0.0133 & 0.0142 & $0-0.03$ & 0.0207 & \begin{tabular}{|l|}
0.0099 \\
\end{tabular} & $0-0.03$ & 0.0135 & 0.0141 & $0-0.03$ & 0.0113 & 0.0145 & $0-0.03$ \\
\hline Israel & 0.0267 & 0.0092 & $0-0.03$ & 0.0273 & 0.0082 & $0-0.03$ & 0.0272 & 0.0085 & $0-0.03$ & 0.0260 & 0.0099 & $0-0.03$ \\
\hline Mexico & 0.0240 & 0.0109 & $0-0.03$ & 0.0233 & 0.0109 & $0-0.03$ & 0.0240 & 0.0107 & $0-0.03$ & 0.0242 & 0.0112 & $0-0.03$ \\
\hline Peru & 0.0249 & 0.0108 & $0-0.03$ & 0.0295 & \begin{tabular}{|l|}
0.0039 \\
\end{tabular} & $0-0.03$ & 0.0285 & 0.0060 & $0-0.03$ & 0.0205 & 0.0134 & $0-0.03$ \\
\hline Philippines & 0.0159 & 0.0143 & $0-0.03$ & 0.0292 & 0.0044 & $0-0.03$ & 0.0190 & 0.0130 & $0-0.03$ & 0.0099 & 0.0140 & $0-0.03$ \\
\hline Poland & 0.0215 & 0.0127 & $0-0.03$ & 0.0286 & 0.0057 & $0-0.03$ & 0.0258 & 0.0092 & $0-0.03$ & 0.0159 & 0.0142 & $0-0.03$ \\
\hline Russia & 0.0114 & 0.0119 & $0-0.03$ & 0.0073 & 0.0110 & $0-0.03$ & 0.0102 & 0.0118 & $0-0.03$ & 0.0135 & 0.0120 & $0-0.03$ \\
\hline $\begin{array}{l}\text { South } \\
\text { Africa }\end{array}$ & 0.0218 & 0.0128 & $0-0.03$ & 0.0295 & 0.0039 & $0-0.03$ & 0.0278 & 0.0068 & $0-0.03$ & 0.0145 & 0.0143 & $0-0.03$ \\
\hline $\begin{array}{l}\text { South } \\
\text { Korea }\end{array}$ & 0.0152 & 0.0132 & $0-0.03$ & 0.0178 & 0.0102 & $0-0.03$ & 0.0150 & 0.0125 & $0-0.03$ & 0.0148 & 0.0143 & $0-0.03$ \\
\hline Sri Lanka & 0.0225 & 0.0125 & $0-0.03$ & 0.0295 & 0.0039 & $0-0.03$ & 0.0286 & 0.0055 & $0-0.03$ & 0.0152 & 0.0145 & $0-0.03$ \\
\hline Taiwan & 0.0241 & 0.0112 & $0-0.03$ & 0.0290 & 0.0054 & $0-0.03$ & 0.0282 & 0.0063 & $0-0.03$ & 0.0190 & 0.0134 & $0-0.03$ \\
\hline Thailand & 0.0131 & 0.0141 & $0-0.03$ & 0.0208 & 0.0115 & $0-0.03$ & 0.0128 & 0.0138 & $0-0.03$ & 0.0115 & 0.0143 & $0-0.03$ \\
\hline Venezuela & 0.0217 & 0.0118 & $0-0.03$ & 0.0277 & 0.0056 & $0-0.03$ & 0.0253 & 0.0082 & $0-0.03$ & 0.0171 & 0.0138 & $0-0.03$ \\
\hline S\&P 500 & 0.6174 & 0.1670 & $0.43-1$ & 0.5220 & 0.0881 & $0.43-1$ & 0.5695 & 0.1205 & $0.43-1$ & 0.6840 & 0.1908 & $0.43-1$ \\
\hline
\end{tabular}




\section{Figure 1: Average Correlations of Emerging Market Returns with S\&P 500 Index Returns}

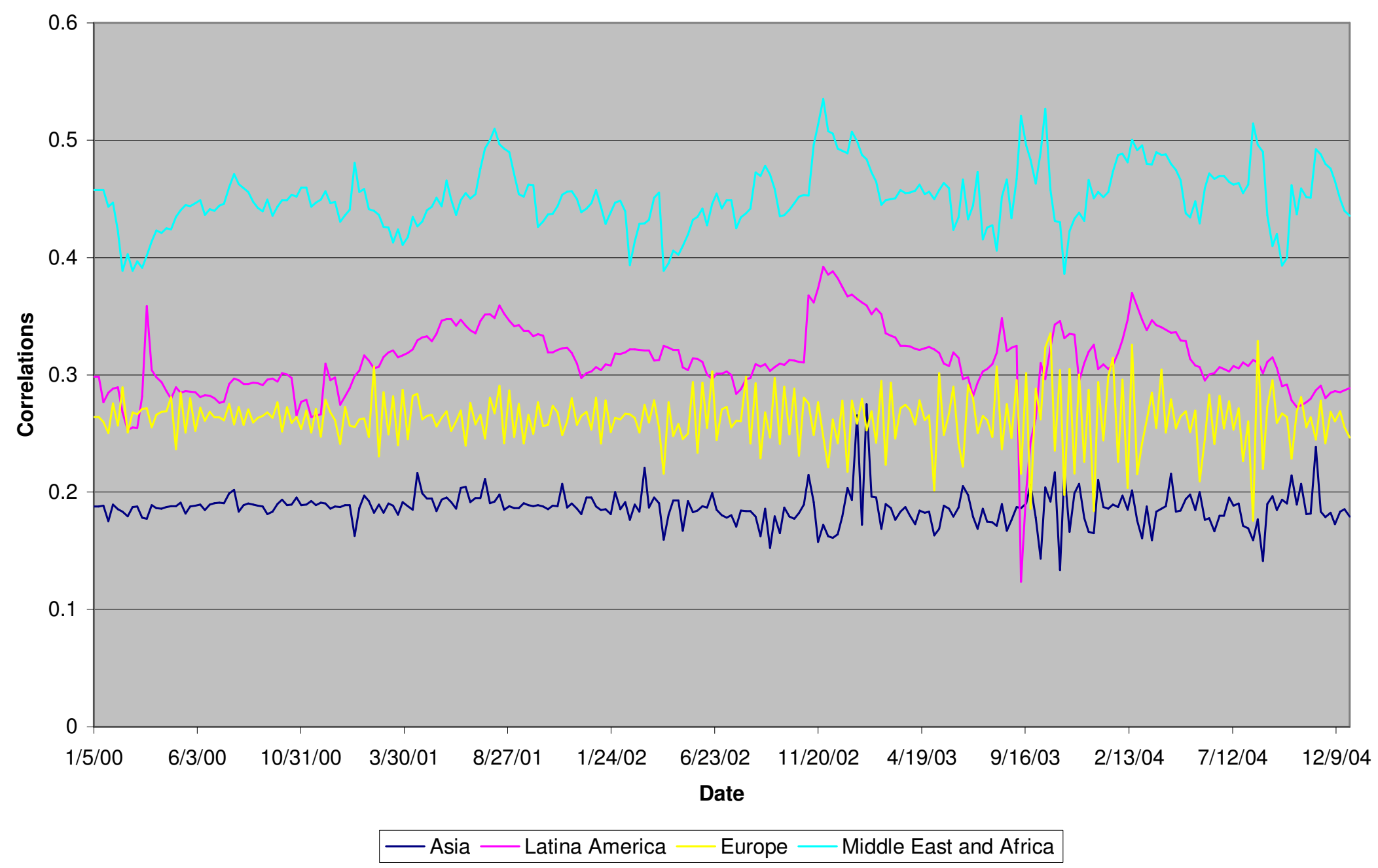

